Proc. Estonian Acad. Sci. Geol., 2000, 49, 1, 3-16

\title{
THE BILLINGEN AND VOLKHOV STAGES IN THE NORTHERN EAST BALTIC: DETAILED STRATIGRAPHY AND LITHOFACIES ZONATION
}

\author{
Andrei DRONOV ${ }^{\mathrm{a}}$, Tõnu MEIDLA ${ }^{\mathrm{b}}$, Leho AINSAAR ${ }^{\mathrm{b}}$, and Oive TINN $^{\mathrm{b}}$
}

${ }^{a}$ Geological Faculty, State University of St. Petersburg, Universitetskaya emb. 7/9, 199034 St. Petersburg, Russia.

b Institute of Geology, University of Tartu, Vanemuise 46, 51014 Tartu, Estonia; tmeidla@math.ut.ee

Received 18 June 1999, in revised form 5 November 1999

\begin{abstract}
The formal stratigraphical subdivision of the Billingen-Volkhov interval is combined with informal detailed subdivision of the Volkhov sequence in the eastern part of the Baltic-Ladoga Klint area. A detailed correlation of the successions east and west of the Narva River is provided, using for the near-klint belt in North Estonia the bed nomenclature employed by Russian quarrymen, and the principal trends of the lithofacies changes in the study area are documented. The affinity of sections in northwestern Russia and Central Estonia is demonstrated and two lithofacies zones within the North Estonian Confacies Belt are distinguished.
\end{abstract}

Key words: Ordovician, Billingen Stage, Volkhov Stage, lithofacies zones, lithostratigraphy, ostracodes, Estonia, northwestern Russia.

\section{INTRODUCTION}

In the East Baltic the early Middle Ordovician carbonate rocks are exposed for $600 \mathrm{~km}$ along the Baltic-Ladoga Klint, a distinctive escarpment ranging in northwestern Russia, North Estonia, and further to the west in the Baltic area. An interval of glauconitiferous limestone was distinguished in this succession already in the early 19th century. The early concepts of this distinct unit (Chloritkalk by Schmidt 1858; Glauconitkalk by Schmidt 1881) form the basis of the modern stratigraphy of the corresponding strata, where they are regarded as the Toila Formation (in North Estonia) or Volkhov Formation (in northwestern Russia). The two formations are roughly equivalent to the Volkhov Stage within the North Estonian Confacies Belt sensu Jaanusson (1976) (see Fig. 1). 


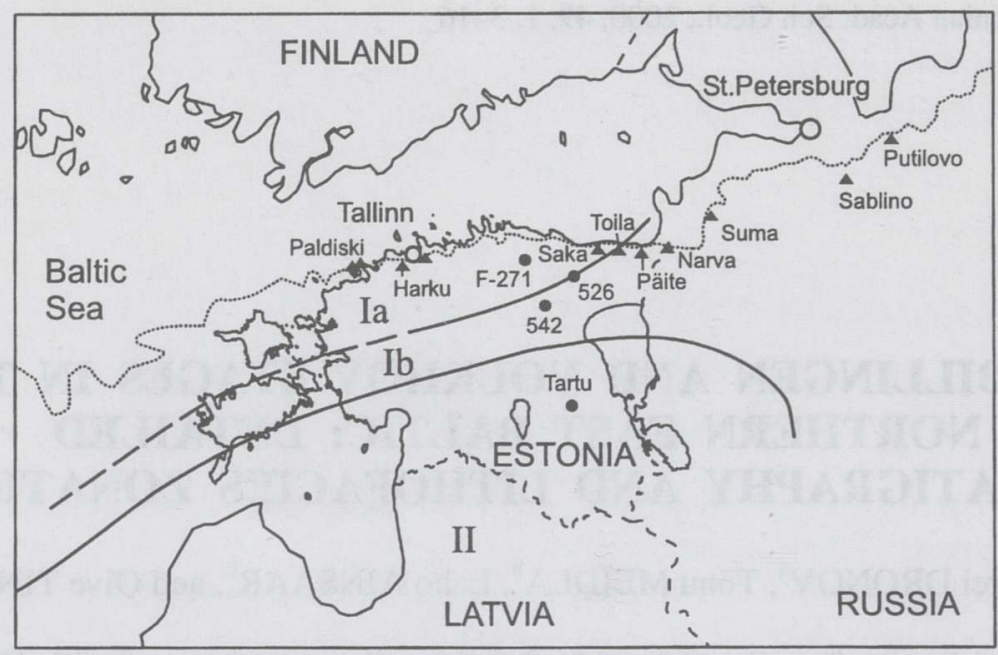

Fig. 1. Location of the sections and approximate position of the lithofacies zones within the eastern part of the Ordovician palaeobasin of Baltoscandia. I, North Estonian Confacies Belt by Jaanusson (1976) (Ia, lithofacies of grey glauconitiferous limestones; Ib, lithofacies of multicoloured limestones); II, Central Baltoscandian Confacies Belt, lithofacies of red-coloured argillaceous limestones; dotted line - Baltic-Ladoga Klint; triangles - outcrops; solid circles - boreholes.

Due to extensive use of Volkhov limestone in the buildings of St. Petersburg and its vicinity, a detailed subdivision of this stratigraphical interval, based on quarrymen's bed names, was introduced about three centuries ago. This subdivision has recently been revived by Dronov et al. $(1993,1996)$ and Dronov \& Fedorov (1995). It consists of 29 individual beds or bedsets and has been established for all principal sections along the Russian part of the Baltic-Ladoga Klint. The beds are distinguished according to the colour, composition, and texture of the rock, along with sedimentary structures, hardground surfaces, and bioturbation.

North of Lake Peipsi, in the vicinity of the Narva River, the Ordovician limestones have been subjected to late diagenetic dolomitization. It has considerably destroyed the palaeontological record in the studied sequence, and therefore the biostratigraphical correlation of the western and eastern near-klint areas has not been revised for a long time. With this background, the use of traditional quarrymen's beds could notably improve the correlation of the Volkhov-Kunda sequence along the Baltic-Ladoga Klint.

The main aim of our investigations was the elaboration of a detailed stratigraphical framework for detailed biofacies analysis and improved correlation. For this purpose, the system of quarrymen's beds was experimentally applied to the Estonian part of the near-klint area. Below, a summary of the corresponding observations is presented together with relevant biostratigraphical information, and an emended lithofacies zonation of the Volkhov sequence is proposed for the eastern Baltic near-klint area. 


\section{STRATIGRAPHICAL SETTING}

The stratigraphical interval under consideration corresponds roughly to Stage $B_{\text {II }}$ by Lamansky (1905). The term "Volkhov Formation" was introduced for it by Raymond (1916), but in a considerably broader meaning, including the underlying glauconite sand- and siltstones as well. The term "Volkhov Stage" was introduced by Rõõmusoks (1956). Later on, this interval was justified and thoroughly described by Orviku (1960), who also introduced the term "Toila Formation" for a rock unit nearly corresponding to the Volkhov Stage in Estonia. The five members of the Toila Formation (Saka, Telinõmme, Künnapõhja, Kalvi, and Lahepera) constitute a threefold subdivision of the Volkhov Stage, which was thought to be consistent with the set of eastern Baltic substadial units (from the base: Saka, Vääna, and Langevoja substages after Männil 1987). The lowermost part of the Toila Formation, the Päite Member, contains Megistaspis estonica indicating the late Billingen age (Mägi 1990).

In northwestern Russia, the term "Volkhov Formation" survived as the name for a lithostratigraphic unit roughly corresponding to the Volkhov Stage. Its threefold subdivision into lower, middle, and upper subformations follows the scheme by Lamansky (1905), which in turn reflects the traditional subdivision of this stratigraphic interval into Dikari, Zheltyaki, and Frizy limestones by local quarrymen.

The biostratigraphy of the interval was first described by Lamansky (1905) and later on introduced for northern Estonia by Orviku (1960). It has also been discussed in several recent papers (Männil \& Meidla 1994; Dronov et al. 1996; Meidla 1997).

\section{BED-BY-BED CORRELATION}

The hard, well-bedded Dikari Limestone has been extensively quarried since the foundation of St. Petersburg. The most important quarries were situated along the Volkhov and Tosna rivers and near the klint edge, in the vicinity of the village of Putilovo. The last quarry is still operating. Due to the commercial interest in this limestone as building material, a number of quarrymen's beds and/or sets of beds with traditional descriptive names were distinguished within the Dikari and overlying Zheltyaki and Frizy limestones during quarry work.

Recent investigations by Dronov and others (Dronov et al. 1993, 1996, 1998; Dronov \& Fedorov 1995) have shown that these individual beds can be recognized in natural outcrops and quarries along the whole Russian segment of the Baltic-Ladoga Klint. Altogether the Upper Billingen-Volkhov interval in Russia consists of 29 individual beds (15 beds in Dikari, 7 in Zheltyaki, and 7 in Frizy limestones), ranging in thickness from 1 to $70 \mathrm{~cm}$. The beds are recognizable in the field due to their characteristic features such as rock type, colour, position in the section, specific hardground surfaces, distribution of 
glauconite grains, trace fossils, etc. Traceability of the beds over a large area, from the easternmost part of the Baltic-Ladoga Klint to northeastern Estonia, reflects the persistence of their lithological characteristics and makes them an ideal framework for precise event-stratigraphic correlation.

In the St. Petersburg Region, 15 quarrymen's beds can be recognized in the Dikari Limestone (Dronov et al. 1993, 1996). Its lower (Billingen age) part consists of four beds forming a shallowing upward succession. The two lower beds (Barkhat and Melkotsvet, indexed as Bh and $\mathrm{Ml}$ in Fig. 2) are characterized by marl and bioclastic wackestone with rare glauconite grains; the Krasnenkij Bed $(\mathrm{Kn})$ is represented by red-coloured marl with yellow hardground surfaces of goethitic impregnation and without visible glauconite. It is overlain by a relatively thick $(20 \mathrm{~cm})$ bed of bioclastic packstone or grainstone with numerous scattered glauconite grains (Beloglaz - Bg; for details see Dronov et al. 1996).

The overlying glauconitiferous Zelenyj Bed ( $\mathrm{Zl}$ ) contains one or more hardground surfaces covered with glauconitic lamella and pitted by "amphora-like borings" (Orviku 1960) or Amphorichnus (Männil 1966). In Estonia only one similar hardground surface is usually present at the top of the Päite Member, and this particular surface ("Püstakkiht") has been referred to as the marker of the lower boundary of the Volkhov Stage. The Päite Member, the Zelenyj Bed inclusive, can be attributed to the Billingen Stage in this area. However, in Russia the thickness of the Zelenyj Bed may reach up to $30 \mathrm{~cm}$ and instead of one hardground surface ("Steklo") several hardground surfaces similar to Püstakkiht may be present. Precise stratigraphy of this thin boundary unit is outside the scope of the present investigation. The Zelenyj Bed can be traced as the most prominent regional marker along the klint, from the Syas River in the east up to Paldiski in the west.

The upper part of the Dikari Limestone, which corresponds to the Saka Member in Estonia, consists of ten distinctive beds, from base to top Staritskij (St), Krasnyj (Kr), Butina (Bn), Zheltyj (Jl), Nadzheltyj (Nj), Myagonkij (Mn), Konoplyastyj (Kp), Pereplet (Pr), Bratvennik (Br), and Butok (Bt). The Staritskij and Krasnyj beds are represented by greenish-grey bioclastic packstone and/or grainstone with scattered glauconite grains. The boundary between the Staritskij and Krasnyj beds coincides with a hardground surface impregnated with glauconite. The Krasnyj Bed contains several (2-3) hardground surfaces, penetrated by numerous narrow, vertically oriented borings about $3-5 \mathrm{~cm}$ in height and $2-3 \mathrm{~mm}$ in diameter. These hardgrounds are usually emphasized by red and yellow impregnation. The Staritskij and Krasnyj beds form a distinctive unit, bounded by two reference levels: the Steklo-like surface at the base and the Butina Bed at the top. The latter bed is a red, friable, extensively bioturbated marlstone without glauconite, of variable thickness (1-7 cm, but mainly $3.5-$ $5 \mathrm{~cm}$ ). It marks a rapid short-term transgression and is underlain by a flooding surface. The Zheltyj and Nadzheltyj beds are represented by glauconite-bearing rock, bioclastic wackestone to grainstone. Both beds contain numerous laterally 


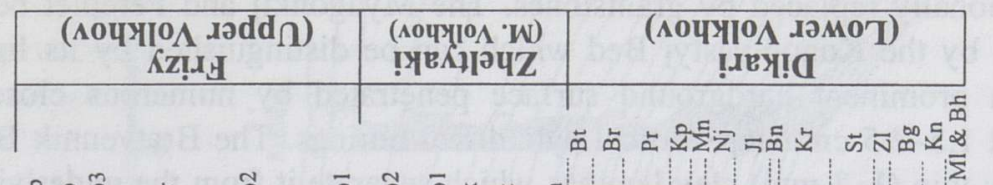

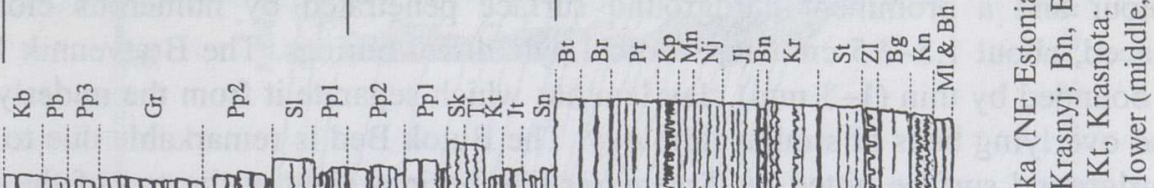
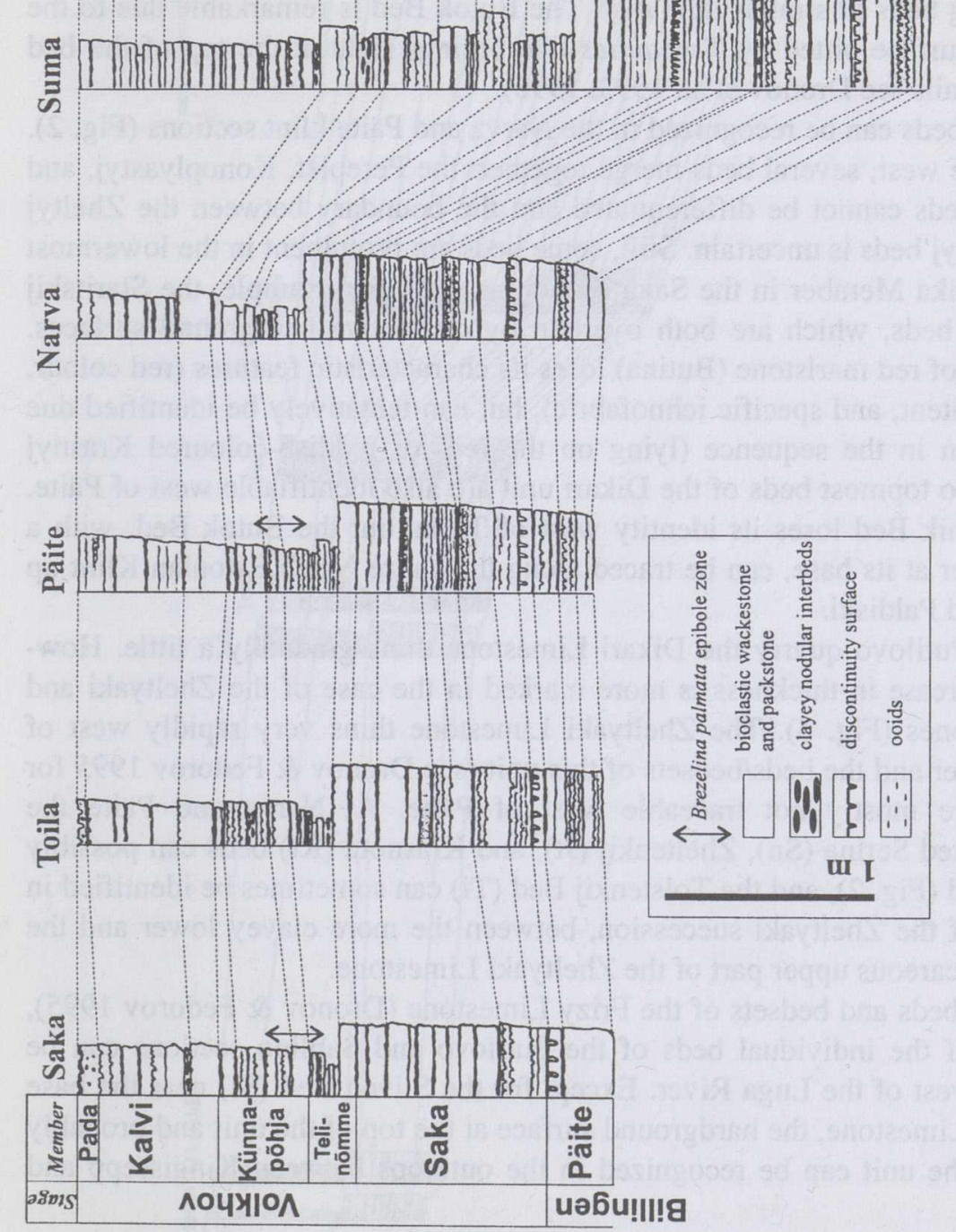

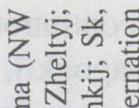
莺

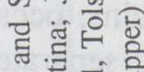
तี 语 1 的语

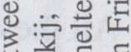
농 ․ㅡ 菏云 炨葛 政...

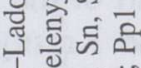

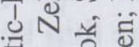

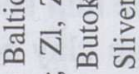
을

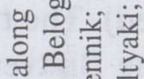

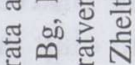

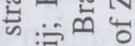
을

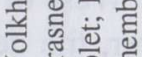
$>$ 은 证漹 品 管

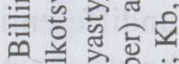
흔 흔 흐을 느의. 运 는은 은 을 뜬 舟 उ o

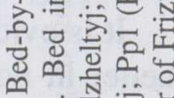

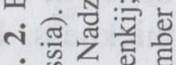

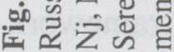


discontinuous yellow and brown hardground surfaces, pitted by borings. The Myagonkij, Pereplet, Bratvennik, and Butok beds are similar in their lithology. They are formed of greenish-grey bioclastic packstone with scattered glauconite grains, occasionally replaced by grainstones. The Myagonkij and Pereplet beds are separated by the Konoplyastyj Bed which can be distinguished by its light colour and a prominent hardground surface penetrated by numerous closely spaced, about $1.5-2.5 \mathrm{~cm}$ deep vertical cylindrical borings. The Bratvennik Bed is bounded by thin $(1-3 \mathrm{~mm})$ clay laminas which separate it from the underlying and overlying beds of similar lithology. The Butok Bed is remarkable due to the hardground surface pitted by Trypanites-like borings right at the top of the bed (for more details see Dronov et al. 1993, 1996).

All these beds can be recognized in the Narva and Päite klint sections (Fig. 2). Further to the west, several beds merge together: the Pereplet, Konoplyastyj, and Myagonkij beds cannot be differentiated and the boundary between the Zheltyj and Nadzheltyj beds is uncertain. Still, some beds are prominent in the lowermost part of the Saka Member in the Saka section as well, for example, the Staritskij and Krasnyj beds, which are both overlain by distinctive hardground surfaces. The thin bed of red marlstone (Butina) loses its characteristic features (red colour, high clay content, and specific ichnofabric), but can tentatively be identified due to its position in the sequence (lying on the red- or reddish-coloured Krasnyj Bed). The two topmost beds of the Dikari unit are also identifiable west of Päite. The Bratvennik Bed loses its identity west of Toila, but the Butok Bed, with a thin clay layer at its base, can be traced along the entire North Estonian Klint up to Tallinn and Paldiski.

West of Putilovo quarry the Dikari Limestone thins gradually a little. However, the decrease in thickness is more marked in the case of the Zheltyaki and Frizy limestones (Fig. 3). The Zheltyaki Limestone thins very rapidly west of the Luga River and the beds/bedsets of this unit (see Dronov \& Fedorov 1995 for reference) are mostly not traceable west of Päite. At Narva and Päite the undifferentiated Serina (Sn), Zheltenkij (Jt), and Krasnota (Kt) beds can possibly be recognized (Fig. 2), and the Tolstenkij Bed (Tl) can sometimes be identified in the middle of the Zheltyaki succession, between the more clayey lower and the relatively calcareous upper part of the Zheltyaki Limestone.

Of seven beds and bedsets of the Frizy Limestone (Dronov \& Fedorov 1995), hardly any of the individual beds of the Putilovo and Sablino sections can be established west of the Luga River. Except for the Sliven Bed ( $\mathrm{Sl}$ ) near the base of the Frizy Limestone, the hardground surface at the top of the unit and probably the base of the unit can be recognized in the outcrops between Kingissepp and Saka (Fig. 2).

It is evident that the quarrymen's beds of the St. Petersburg area can be traced better in northeastern Estonia, within the part of the sequence of a more stable thickness. For this particular part of the Estonian sequence the stratigraphical framework can be elaborated in greater detail than previously expected. 


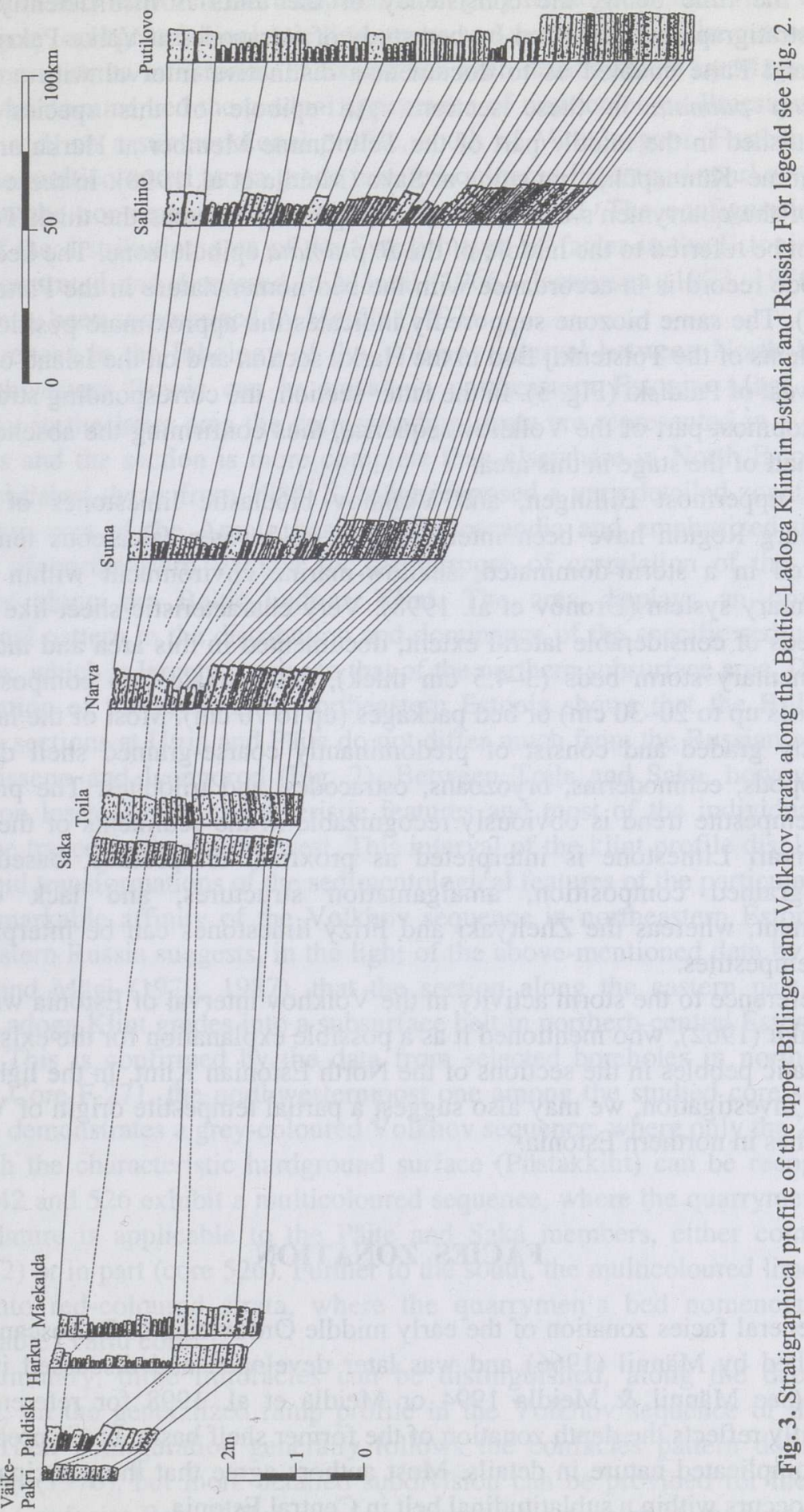


For the time being, the consistency of the units is insufficiently proved by biostratigraphical data. Bed-by-bed study of ostracodes at Väike-Pakri, Harku, Saka, and Päite enabled us to document a distinctive interval with a flood of Brezelina palmata in these sections. An epibole of this species can be distinguished in the middle part of the Telinõmme Member at Harku and at the Telinõmme-Künnapõhja transition at Saka (Meidla et al. 1998). In these sections some of the quarrymen's beds are well recognized, whereas the thick Tolstenkij Bed can be referred to the middle of the B. palmata epibole zone. The bed-by-bed ostracode record is in accordance with the bed nomenclature in the Päite section (Fig. 2). The same biozone supposedly indicates the approximate position of the equivalents of the Tolstenkij Bed in the Harku section and on the Island of VäikePakri west of Paldiski (Fig. 3). In the latter section, the corresponding strata occur in the topmost part of the Volkhov sequence, thus confirming the absence of the upper half of the stage in this area.

The uppermost Billingen, and Volkhov bioclastic limestones of the St. Petersburg Region have been interpreted as cold-water calcareous tempestites deposited in a storm-dominated, shallow-marine environment within a ramp sedimentary system (Dronov et al. 1998). Very characteristic sheet-like skeletal sand beds of considerable lateral extent, documented in this area and interpreted as elementary storm beds ( $3-4.5 \mathrm{~cm}$ thick), amalgamate into composite beds (thickness up to 20-30 cm) or bed packages (up to $70 \mathrm{~cm}$ ). Most of the layers are distinctly graded and consist of predominantly coarse-grained shell debris of brachiopods, echinoderms, bryozoans, ostracodes, and trilobites. The proximaldistal tempestite trend is obviously recognizable in the sediments of the region. The Dikari Limestone is interpreted as proximal tempestites, based on its coarse-grained composition, amalgamation structures, and lack of clay component, whereas the Zheltyaki and Frizy limestones can be interpreted as distal tempestites.

A reference to the storm activity in the Volkhov interval of Estonia was made by Orviku (1962), who mentioned it as a possible explanation for the existence of phosphatic pebbles in the sections of the North Estonian Klint. In the light of the present investigation, we may also suggest a partial tempestite origin of Volkhov limestones in northern Estonia.

\section{FACIES ZONATION}

A general facies zonation of the early middle Ordovician of Baltoscandia was established by Männil (1966) and was later developed and discussed in many papers (see Männil \& Meidla 1994 or Meidla et al. 1998 for references). It apparently reflects the depth zonation of the former shelf basin, but is probably of more complicated nature in details. Most authors agree that the principal facies change occurs within a sublatitudinal belt in Central Estonia. 
Põlma (1982) mentions the transition from grey to multicoloured (red, brown, yellow, grey, and green) bioclastic limestones and marls south of the outcrop area of the Arenig strata in Estonia. The same has been demonstrated by Mägi (1970, 1987), who documented the gradual appearance of multicoloured limestones east of Ardu and, on a submeridional profile, south of Viru-Jaagupi. Further to the south, the multicoloured strata grade into red-coloured limestone-marl sequence, similar to the contemporaneous strata in Västergötland. The configuration and extent of the distribution area of the Swedish type of facies in the Estonian area are demonstrated and discussed in Männil (1966), Jaanusson (1973, 1976), and has recently been summarized by Meidla (1997).

Differences in the lithology of the Volkhov interval between North Estonia and northwestern Russia can be traced in northeastern Estonia. Mägi (1981) stated that in the latter area the corresponding strata are represented in a greater thickness and the section is more complete than elsewhere in North Estonia. In her unpublished thesis from 1984, S. Mägi proposed a very detailed zonation for the eastern part of the Arenig basin of Baltoscandia and emphasized the key position of northeastern Estonia for the purpose of correlation of the Ontika Subseries along the Baltic-Ladoga Klint. The area displays an obviously transitional pattern in the distribution and dominance of the specific sedimentary structures, which is largely similar to that of the northern subsurface area. Detailed investigation of the sections in northeastern Estonia shows that the BillingenVolkhov sections at Utria and Päite do not differ much from the Russian sections of Kingissepp and Ivangorod (Fig. 2). Between Toila and Saka, however, the succession loses several characteristic features and most of the individual beds cannot be traced further to the west. This interval of the klint profile displays the most rapid transformations of the sedimentological features of the particular beds.

A remarkable affinity of the Volkhov sequence in northeastern Estonia and northwestern Russia suggests, in the light of the above-mentioned data by Põlma (1982) and Mägi $(1970,1987)$, that the section along the eastern part of the Baltic-Ladoga Klint grades into a subsurface belt in northern-central Estonia (see Fig. 1). This is confirmed by the data from selected boreholes in northeastern Estonia. Core F-271, the northwesternmost one among the studied core sections (Fig. 1), demonstrates a grey-coloured Volkhov sequence, where only the Zelenyj Bed with the characteristic hardground surface (Püstakkiht) can be recognized. Cores 542 and 526 exhibit a multicoloured sequence, where the quarrymen's bed nomenclature is applicable to the Päite and Saka members, either completely (core 542) or in part (core 526). Further to the south, the multicoloured limestones grade into red-coloured strata, where the quarrymen's bed nomenclature is inapplicable (Tartu core).

In summary, three lithofacies can be distinguished, along the deepening gradient, on the generalized ramp profile in the Volkhov sequence of the East Baltic. Their configuration generally follows the confacies pattern defined by Jaanusson (1976), but more detailed subdivision can be provided for the North Estonian Confacies Belt. Differently from Jaanusson's concept of confacies which 
is based on the integrity of the sedimentological and palaeontological criteria, the zonation described below is based on the sedimentological observations only.

Within the North Estonian Confacies Belt, the lithofacies of grey-coloured limestones (Ia) and the lithofacies of multicoloured limestones (Ib) can be distinguished (Fig. 1).

The grey-coloured lithofacies belt (Ia) embraces northern and northwestern Estonia and is represented by bioclastic wackestones and packstones with bluish-grey clay intercalations and scattered well-developed glauconite grains, and by hardground surfaces of yellow goethitic impregnation. The sediments are relatively coarse-grained and thick-bedded.

The multicoloured (red, brown, yellow, green, and grey) lithofacies belt (Ib) can be traced in natural outcrops in northwestern Russia, northeastern Estonia, and in a subsurface belt in Central Estonia. It is represented by well-bedded bioclastic limestones (mudstones to packstones), with hardground and firmground (for the term see Bromley 1996) surfaces of a very characteristic morphology. The limestones are intercalated with variegated red and yellowishred clays in the middle part of the section. Compared to the grey-coloured lithofacies, the deposits are more fine-grained and glauconite grains are rarer and less developed.

The Central Baltoscandian Confacies Belt which is distinguished in southern Estonia on the basis of the core materials, is characterized by red-coloured (argillaceous), fine-grained limestones (mudstones), usually without glauconite.

The multicoloured lithofacies in the Russian part of the Baltic-Ladoga Klint passes westwards into the subsurface of northern-central Estonia and apparently can be traced up to Öland (Männil 1966, fig. 52). Within zone Ib lateral changes take place (Fig. 1), as shown also by Mägi (1981), and thus the individual beds of the East Baltic-Ladoga Klint area cannot probably be traced from Russia to Öland. Nevertheless, it is obvious that the Öland multicoloured facies occupies the same transitional position on the general facies profile as the multicoloured facies in the eastern part of the palaeobasin.

\section{REMARKS ON STRATIGRAPHICAL NOMENCLATURE}

The use of substadial units of the Volkhov Stage in North Estonia is limited due to scarcity of the trilobite and conodont record. The members of the Toila Formation are the most widely used subunits. They are thought to be consistent with the substages in the klint sections, but this consideration is mainly based on tracing the levels of the most evident lithological changes in the sections with palaeontological record. The detailed chronostratigraphy, applied to the eastern part of the Baltic-Ladoga Klint area, could be effectively used for further development of the Billingen-Volkhov stratigraphy in northeastern Estonia. Tracing the marker beds enabled us to demonstrate the relation of the tripartite 
subdivisions of the Volkhov Stage, traditionally applied in the western St. Petersburg Region and in northwestern Estonia (Fig. 2), which are nearly equivalent, but inconsistent in details.

Männil (1966) excludes the basal beds of the Volkhov and Toila formations from the Volkhov Stage. He emphasizes the occurrence of Megistaspis estonica in the Päite Member and assigns the unit to the Billingen Substage (or Stage in nowadays meaning). The lower boundary of the stage is moved by him to the so-called Steklo or Püstakkiht nondepositional surface within the Toila Formation/Dikari Limestone. Hence, the terms "Volkhov Formation" and "Volkhov Stage" actually defined different intervals in the sequence. Based on a decision of the Stratigraphic Committee of the former USSR (Männil 1987), in some recent papers (Dronov et al. 1996, 1998) the term "Volkhov Formation" has also been applied in a more restricted sense. To avoid a confusion, it is reasonable to use the term "Volkhov Formation" in the original sense of "Stage $\mathrm{B}_{\text {III }}$ " by Lamansky (1905), that is, the equivalents of the Päite Member inclusive. This consideration is supported by the integrity of the Dikari traditional unit, confirmed by great lithological similarity between its lower beds and the main part.

\section{CONCLUSIONS}

1. The informal Russian bed nomenclature can be applied in detailed correlation of the uppermost Billingen and Volkhov interval in northeastern Estonia. Most of the individual beds recognized in the western St. Petersburg Region can be traced along the klint line for up to $50 \mathrm{~km}$ west of the Narva River. They are also identifiable in the cores of northeastern Estonia.

2. Two lithofacies zones can be distinguished within the North Estonian Confacies Belt in the sense of Jaanusson (1976): the grey-coloured onshore lithofacies and the multicoloured offshore lithofacies. Difference in the lithostratigraphic nomenclature applied to the Volkhov sequence of Estonia and Russia is apparently due to this lithofacies differentiation.

3. The concept of the Volkhov Formation in the original sense of "Stage $\mathrm{B}_{\mathrm{II}}$ " by Lamansky (1905), that is, the equivalents of the Päite Member inclusive, is supported by the integrity of the Dikari traditional unit, proved by a high lithological similarity of the corresponding individual beds.

\section{ACKNOWLEDGEMENTS}

This work was financially supported by the Estonian Science Foundation (grant 3011) and by the Russian Foundation for Fundamental Investigations (grant No. 98-05-65065). A. Dronov acknowledges the financial support from the Institute of Geology, University of Tartu, during his visit to Estonia in late 1998. 


\section{REFERENCES}

Bromley, R. G. 1996. Trace Fossils. Biology, Taphonomy and Applications. Chapman \& Hall, London.

Dronov, A. V. \& Fedorov, P. V. 1995. Ordovician carbonates of the St. Petersburg region: stratigraphy of the Zheltyaki and Frizy beds. Vestnik S.-Peterburgskogo univ., ser. 7. Geologiya, geografiya, 2, 9-16 (in Russian).

Dronov, A. V., Savitskij, Yu. V. \& Tsyganova, E. A. 1993. Ordovician carbonates of the St. Petersburg region: stratigraphy of the Dikari Unit. Vestnik S.-Peterburgskogo univ., ser. 7. Geologiya, geografiya, 3, 36-42 (in Russian).

Dronov, A. V., Savitsky, J. V., Fedorov, P. V. \& Tsyganova, E. A. 1996. Detailed lithostratigraphy of the Ordovician lower Volkhovian limestone along the eastern part of the Baltic-Ladoga Glint, northwestern Russia. GFF, 118, 19-24.

Dronov, A. V., Koren, T. N., Popov, L. E. \& Tolmacheva, T. Yu. 1998. Event Stratigraphy Approach Applied to Regional Correlation. VSEGEI, St. Petersburg (in Russian).

Jaanusson, V. 1973. Aspects of carbonate sedimentation in the Ordovician of Baltoscandia. Lethaia, 6, 11-34.

Jaanusson, V. 1976. Faunal dynamics in the Middle Ordovician (Viruan) of Balto-Scandia. In The Ordovician System: Proceedings of a Palaeontological Association Symposium (Basset, M. G., ed.), pp. 301-326. Univ. Wales Pr.

Lamansky, V. V. 1905. Die aeltesten silurischen Schichten Russlands (Etage B). Tr. Geol. Komiteta. N. S., 20. St. Petersburg (in Russian).

Mägi, S. 1970. The Ontikan rocks in Central and West Estonia. ENSV TA Toim. Keem. Geol., 19, 141-146 (in Russian).

Mägi, S. 1981. Tektooniliste tingimuste kajastumine Eesti alamordoviitsiumis. In Settekivimid ja tektoonika (Pirrus, E., ed.), pp. 71-93. Eesti Looduseuurijate Selts, Tallinn.

Mägi, S. 1987. The Volkhov Stage. In Geology and Mineral Resources of the Rakvere PhosphoriteBearing Area (Puura, V., ed.), pp. 41-42. Valgus, Tallinn (in Russian).

Mägi, S. 1990. Locality 1:4. Mäekalda road excavation. In Field Meeting Estonia 1990: An Excursion Guidebook (Kaljo, D. \& Nestor, H., eds.), pp. 124-127. Estonian Acad. Sci., Tallinn.

Männil, R. 1966. Istoriya razvitiya Baltijskogo bassejna v ordovike. Valgus, Tallinn (in Russian).

Männil, R. 1987. Explanatory notes to the stratigraphical charts of the Ordovician deposits. In Resheniya mezhvedomstvennogo stratigraficheskogo soveschaniya po ordoviku $i$ siluru Vostochno-Evropejskoj platformy, 1984 g. (Kaljo, D. L., ed.), pp. 17-57. Leningrad (in Russian).

Männil, R. \& Meidla, T. 1994. The Ordovician System of the East European Platform (Estonia, Latvia, Lithuania, Byelorussia, parts of Russia, the Ukraine and Moldova). In The Ordovician System of the East European Platform and Tuva (Southeastern Russia), A (Webby, B. D., Ross, R. J. Jr. \& Zhen, Y. Y., eds.). IUGS Publication, 28, 1-52.

Meidla, T. 1997. Volkhov Stage. In Geology and Mineral Resources of Estonia (Raukas, A. \& Teedumäe, A., eds.), pp. 61-64. Estonian Acad. Publ., Tallinn.

Meidla, T., Ainsaar, L. \& Tinn, O. 1998. Volkhov Stage in North Estonia and sea level changes. Proc. Estonian Acad. Sci. Geol., 47, 141-157.

Orviku, K. 1960. Über die Lithostratigraphie der Wolchow- und der Kundastufe in Estland. ENSV TA Geol. Inst. Uurimused, 5, 45-87 (in Russian).

Orviku, K. 1962. Über die Gerölle in der Wolchow- und der Kundastufe (Unterordovizium) Estlands. In Geologiya paleozoya (Kaljo, D. \& Männil, R., eds.). ENSV TA Geol. Inst. Uurimused, 10, 187-203 (in Russian).

Põlma, L. 1982. Sravnitel'naya litologiya karbonatnykh porod ordovika Severnoj $i$ Srednej Pribaltiki. Valgus, Tallinn (in Russian). 
Raymond, P. E. 1916. Expedition to the Baltic Provinces of Russia and Scandinavia. Part 1. The correlation of the Ordovician Strata of the Baltic Basin with those of the eastern North America. Bull. Mus. Comp. Zoöl. Harvard Coll., 56, 179-286. Cambridge, Mass., USA.

Rõõmusoks, A. 1956. Biostratigraphical subdivision of the Ordovician of the Estonian S.S.R. ENSV TA Geol. Inst. Uurimused, 1, 9-29 (in Russian).

Schmidt, F. 1858. Untersuchungen über die Silurische Formation von Ehstland, Nord-Livland und Oesel. Arch. Naturk. Liv-, Ehst- und Kurlands, 2.

Schmidt, F. 1881. Revision der ostbaltischen silurischen Trilobiten nebst geognostischer Überschicht des ostbaltischen Silurgebiets. Abt. I. Phacopiden, Cheiruriden und Encrinuriden. Mém. Acad. Imp. Sci. St.-Pétersb., 7e série, 30, 1.

\title{
BILLINGENI JA VOLHOVI LADE PÕHJA-BALTIKUMIS: DETAILSTRATIGRAAFIA JA LITOFATSIAALSED VÖÖNDID
}

\author{
Andrei DRONOV, Tõnu MEIDLA, Leho AINSAAR ja Oive TINN
}

On esitatud Narva jõe lääne- ja idakalda dolomiidistumisest mõjutatud läbilõigete korrelatsioon, mis põhineb Billingeni ja Volhovi lademe kehtiva stratigraafilise liigestuse kombineerimisel Peterburi piirkonna paemurdjate kasutatud traditsioonilise kihilise liigestusega. Viimane koosneb 29 nimelisest kihist või kihtide kompleksist. See liigestus on kasutatav Põhja-Eesti paekalda läbilõigete ja paekaldalähedase ala puursüdamike kirjeldamisel kuni $50 \mathrm{~km}$ ulatuses Narva jõest läänes. Loode-Venemaa ja kirdepoolse Eesti läbilõigete suurele sarnasusele tuginedes on Põhja-Eesti konfatsiaalse vööndi ulatuses võimalik piiritleda kahte litofaatsiest, mis makroskoopiliselt eristuvad teineteisest lubjakivide värvuse ja glaukoniidisisalduse alusel ning seostuvad paleobasseini erinevate sügavusvöönditega. Dikari kihindi üksikkihtide ühetaolisuse tõttu on soovitav LoodeVenemaa Volhovi kihistu käsitlemisel lähtuda Lamansky (1905) määratlusest, s.o. arvata Volhovi kihistu koosseisu ka Dikari kihtide basaalne osa, mille moodustavad Päite kihistiku ekvivalendid.

\section{БИЛЛИНГЕНСКИЙ И ВОЛХОВСКИЙ ГОРИЗОНТЫ В СЕВЕРНОЙ ПРИБАЛТИКЕ: ДЕТАЛЬНАЯ СТРАТИГРАФИЯ И ЛИТОФАЦИИ}

\author{
Андрей ДРОНОВ, Тыну МЕЙДЛА, Лехо АЙНСААР и ОЙве ТИНН
}

Представлена корреляция доломитизированных разрезов западнее и восточнее р. Нарва, оснөванная на комбинации современного стратиграфического расчленения биллингенского и волховского горизонтов с традиционным разделением данного интервала на пласты. Расчленение на пласты в течение последних столетий использовалось в каменоломнях 
окрестностей Санкт-Петербурга. Выделенные 29 индивидуальных пластов или их комплексов приемлемы для расчленения разрезов в североэстонской части глинта и приглинтовой области на протяжении до 50 км западнее от р. Нарва. Исходя из сходства разрезов Северо-Западной России и Северо-Восточной Эстонии можно в пределах северо-эстонской конфациальной зоны разграничить две литофации, макроскопически различающиеся цветом пород и содержанием в них глауконита, которые отражают глубинную зональность палеобассейна. На основании большого сходства отдельных пластов толщи "дикарей" считается целесообразным при рассмотрении волховской свиты в Северо-Западной России исходить из концепции Ламанского (1905), т. е. включать в состав волховской свиты и базальную часть "дикарей" (эквиваленты пяйтеской пачки). 